\title{
PEMANFAATAN MEDIA SOSIAL SEBAGAI STRATEGI KEHUMASAN DIGITAL DI ERA REVOLUSI INDUSTRI 4.0
}

\author{
Dina Mizanie ${ }^{1}$, Irwansyah ${ }^{2}$ \\ ${ }^{1}$ Mahasiswa Pascasarjana Manajemen Komunikasi \\ Fakultas Ilmu Sosial dan Ilmu Politik Universitas Indonesia, \\ Email : dina.mizanie@live.com \\ ${ }^{2}$ Dosen Pengajar Pascasarjana Manajemen Komunikasi \\ Fakultas Ilmu Sosial dan Ilmu Politik Universitas Indonesia, \\ Email : dr.irwansyah.ma@gmail.com
}

\begin{abstract}
The use of internet and digitalization brought the world towards the fourth industrial revolution or industry 4.0. The characteristic of industry 4.0 is a combination between internet devices and human performance or cyber-physical system. Industry 4.0 provided new public relations strategies to develop. This study aims to discuss more about how the digital public relations in the way to achieve goals which building the reputation. The strategies described in this study focused on social media including electronic word-of-mouth (e-WOM), internet buzzer, social media activist and search engine optimization
\end{abstract}

.Keywords: Digital public relations, industry 4.0, social media, industrial internet, strategy management

\section{ABSTRAK}

Pemanfaatan internet dan digitalisasi membawa masyarakat dunia menuju revolusi industri keempat atau industri 4.0. Era industri 4.0 memiliki karakteristik kombinasi antara perangkat internet dengan kinerja manusia atau cyber-physical system ternyata memberikan banyakstrategi komunikasi hubungan masyarakat untuk dikembangkan. Kajian ini bertujuan untuk membahas lebih dalam bagaimana strategi hubungan masyarakat digital dalam usahanya mencapai tujuannya membangun reputasi. Strategi yang diuraikan dalam kajian ini berfokus pada media sosial yang berbentuk electronic wordof-mouth (e-WOM), internet buzzer, aktivis media sosial, dan penggunaan search engine optimization.

Kata Kunci: Hubungan masyarakat digital, industri 4.0, media sosial, industri internet, manajemen strategi.

\section{PENDAHULUAN}

Revolusi industri ramai dibicarakan beberapa tahun belakangan ini. Saat ini dunia dikatakan sedang memasuki era keempat dalam revolusi. Sebelum era keempat atau yang sering disebut sebagai revolusi industri 4.0, setiap era dalam revolusi industri memiliki karakteristiknya masing-masing. Pada era revolusi pertama atau yang dikenal dengan industri 1.0, karakteristiknya adalah tumbuhnya industri yang menggunakan alat mekanis yang menggunakan tenaga air dan uap. Industri 2.0 ditandai dengan produksi massal, perakitan produk dan munculnya pemanfaatan tenaga listrik. Selanjutnya industri 3.0 membawa karakteristik penggunaan komputer dan mesin-mesin yang 
berjalan otomatis. Kemudian industri terus berevolusi hingga muncul istilah revolusi industri 4.0 yang ditandai dengan sistem cyber-physical (Fuchs, 2018), yaitu terjadinya kolaborasi antara kegiatan fisik di dunia nyata dengan kegiatan siber di dunia internet.

Istilah industri 4.0 ini pertama kali dicetuskan oleh pemerintahan Jerman pada 2011 dalam acara Hannover Fair. Mereka menyebutkan ini sebagai awal dari revolusi industri keempat (Ustundag \& Cevikcan, 2018). Perdebatanmengenaiindustri4.0inicukupramai di Jerman bahkan mereka telah memunculkan konsep ini hingga di ranah pemerintahan, laporan-laporan hingga penelitian (Fuchs, 2018). Secara umum, industri 4.0 ini sering dikaitkan dengan kemunculan internet yang memungkinkan alat-alat saling terhubung serta para pengguna juga dapat saling berinteraksi. Industri 4.0 juga dikatakan mengoptimalkan elemen operasionalisasi, komunikasi dan teknologi informasi untuk membuat proses otomatisasi dalam manufaktur dapat maksimal (Gilchrist, 2016). Fuchs menjelaskan bahwa hal terekstrim dari industri 4.0 adalah "suatu barang sepenuhnya diproduksi, dikirim, digunakan, diperbaiki dan didaur ulang secara otomatis tanpa campur tangan manusia, melalui jaringan berbagai teknologi melalui internet" (Fuchs, 2018).

Industri 4.0 awalnya muncul sebagai kelanjutan dari industri 3.0 yang menggunakan komputer dan mengandalkan otomatisasi oleh mesin. Namun meskipun sebuah fase kelanjutan, tidak menjadikan konsep ini hanya dapat diterapkan dalam industri yang bersifat mekanik seperti mesin-mesin pabrik saja. Penggunaan internet memberikan peluang untuk munculnya solusi baru di bidang lain, salah satunya dalam bidang komunikasi. Sama seperti proses industri, komunikasi juga mengalami tahapan dari tradisional, mekanik, komputerisasi hingga pemanfaatan internet. Revolusi industri 4.0 memungkinkan kegiatan komunikasi yang perlu menyentuh khalayak yang lebih luas berjalan lebih optimal. Hal ini didukung dengan internet yang memiliki kelebihan untuk menjangkau khalayak yang tidak terbatas pada geografis. Penerapan pada bidang komunikasi massa misalnya muncul media-media baru yang berbasis internet. Surat kabar yang tadinya berbentuk cetak kini dapat diakses bentuk digitalnya melalui situs resmi kantor beritanya. Bahkan, internet memberikan peluang untuk mendapatkan laporan berita tepat ketika suatu kejadian terjadi. Begitu pula dengan radio yang pada era industri sebelumnya mengandalkan sinyal analog, memasuki era industri 4.0 mulai berkembang menggunakan radio digital, lebih jauh menggunakan koneksi internet untuk menghadirkan radio streaming.

Sebagai salah satu bidang komunikasi yang memerlukan kemampuan untuk menjangkau publik yang besar untuk kepentingan membangun reputasi yang baik bagi organisasi, bidang hubungan masyarakat cukup diuntungkan dengan kehadiran industri 4.0 ini. Kehumasan mengalami perkembangan seiring dengan berkembangnya teknologi. Era digitalisasi juga berperan besar dalam kemajuan industri kehumasan. Pada era industri sebelumnya kegiatan humas masih berkutat pada hal yang bersifat analog. Perangkat penyebaran pesan terkait reputasi dan citra organisasi yang digunakan masih berupa artefak seperti rilis yang diterbitkan di koran dan sebagainya. Salah 
satu kekurangan kegiatan humas analog ini adalah sulit untuk menjangkau khalayak yang lebih besar karena sangat terbatas oleh jumlah pembaca yang mampu mengakses media-media tersebut. Sementara sekarang ini digitalisasi memungkinkan kegiatan kehumasan dijalankan secara digital melalui internet. Perubahan ini membuka kesempatan bagi strategi baru untuk tumbuh seperti internet buzzer, aktivis media sosial, hingga berkembangnya konsep word-of-mouth di dunia maya. Dari beberapa strategi kehumasan yang muncul dapat disimpulkan bahwa sebagian besar dari strategi ini menggunakan media sosial. Selain dikarenakan bentuk situs yang beragam dan jumlah penggunanya terus meningkat setiap tahun, media sosial merupakan media tempat individu berdiskusi mengenai berbagi hal. Proses interaksi yang terjadi di media sosial juga cukup unik yaitu memungkin seseorang untuk terhubung dengan orang lain yang tidak dikenalnya, atau bahkan orang tersebut dapat menggunakan identitas anonim. Media sosial juga merupakan media yang memungkinkan penggunanya untuk mengolah kontennya sendiri atau yang lebih dikenal dengan istilah user-generated content. Media sosial juga memiliki karakteristik yang disebut sharing, yaitu kegiatan antar pengguna yang saling bertukar, mendistribusikan dan menerima konten (Kietzmann, Hermkens, McCarthy, \& Silvestre, 2011). Dari sharing ini kemudian memungkinkan suatu konten dapat menjadi viral dan pesan dapat tersebar dengan luas dan cepat, tanpa perlu lebih banyak tenaga karena penyebarannya dilakukan oleh penggunanya sendiri. Kemungkinan untuk masifnya suatu pesan ini dapat dipertimbangkan oleh humas dalam melakukan kegiatan komunikasi korporat dan kehumasan. Dengan kata lain, menggunakan media sosial sebagai suatu instrumen dalam menjalankan strategi kehumasan memberikan pandangan baru, yaitu bagaimana agar reputasi itu dibangun dengan partisipasi khalayak, tidak hanya dari humas organisasi atau perusahaan saja. Hal yang sama juga diterapkan dalam tujuan humas lainnya seperti mengatasi krisis, manajemen citra dan memanipulasi dukungan publik, semua tujuan ini dapat diusahakan dengan adanya partisipasi khalayak melalui strategi yang akan dibahas.

Berdasarkan uraian di atas, penulis berupaya untuk mengkaji lebih dalam mengenai kegiatan humas digital yang memanfaatkan media sosial. Dalam tulisan ini penulis juga berusaha membangun konseptual dari berbagai sumber tentang strategi-strategi yang akan dibahas sehingga mendapatkan gambaran yang jelas bagaimana setiap strategi bekerja dan agar tetap sejalan dengan konsep-konsep kehumasan maupun industri 4.0. Tulisan ini kemudian dispesifikkan dalam judul "Pemanfaatan Media Sosial Sebagai Strategi Humas Digital di Era Industri 4.0".

\section{METODE PENELITIAN}

Metode yang digunakan dalam kajian ini adalah metode kajian literatur atau studi pustaka. Kajian literatur merupakan metode mengumpulkan teori dan penelitian yang berhubungan dengan topik kajian (Ridley, 2012). Pada kajian ini penulis mengumpulkan berbagai jenis literatur berupa buku, jurnal, dan hasil penelitian terdahulu yang kemudian disusun sesuai dengan pembahasan. Dengan 
adanya tinjauan yang komprehensif diharapkan akan memperkaya konseptual mengenai konsep dan strategi yang akan dibahas.

\section{HASIL DAN PEMBAHASA}

\section{Hubungan Masyarakat dalam Industri 4.0}

Untuk memahami lebih dalam industri 4.0 penting untuk memulai dari definisi yang dirumuskan oleh para ahli yang terkait dengan konsep ini. Beberapa peneliti meyakini bahwa tidak ada definisi yang pasti untuk menjelaskan apa itu industri 4.0, namun agar memiliki pemahaman yang sama penulis mencoba menyajikan definisi dari beberapa peneliti terkait konsep ini. Fuchs mendefinisikan industri 4.0 sebagai "sebuah konsep yang menyebarkan kombinasi Internet of Things (IoT), big data, media sosial, cloud computing, sensor, kecerdasan buatan (artificial intelegence), robotics dan penerapan dari kombinasi ini dalam produksi, distribusi dan penggunaan dari suatu produk fisik" (Fuchs, 2018). Sementara Baldasari dan Roux menjelaskan bahwa inti dari industri 4.0 adalah "cyber-physical system" itu sendiri yaitu dimana terjadi perpaduan antara perangkat keras, perangkat lunak serta manusia untuk melakukan suatu tugas atau pekerjaan (Baldassari \& Roux, 2017). Herman et al (Jankowska \& Götz, 2017) memberikan definisi yang mirip dengan simpulan Fuchs yang mengedepankan teknologinya yaitu industri 4.0 merupakan kesatuan dari empat konsep utama yaitu CPS, IoT, Internet of service dan smart Factory. Dari definisi-definisi yang telah disampaikan, maka dapat disimpulkan bahwa industri 4.0 merupakan konsep yang digunakan dalam memahami kondisi industri yang mengedepankan kombinasi antara ruang siber atau internet bersama sejumlah perangkatnya dengan tenaga manusia.

Industri 4.0 sering kali disebut juga dengan industri internet atau industrial internet. Meskipun dicetuskan oleh Jerman, nyatanya konsep ini menyebar dengan cepat juga ke negara-negara sekitar Amerika dan Asia. Di Amerika konsep ini menjadi alat kunci untuk berbagai strategi pembangunan nasional dan menjadi perspektif yang paling banyak digunakan terkait dengan perkembangan industri teknologi (Popkova, Ragulina, \& Bogoviz, 2019). Sementara di Jepang, pembangunanindustri4.0 telah menjadiprioritas dari implementasi rencana saintek negara tersebut (Popkova et al., 2019). Kepopuleran konsep industri internet ini menurut Gilchrist (2016) didorong oleh kompleksitas sistem industri pada masa sekarang. Sistem industri telah melampaui kemampuan manusia untuk mengarahkan solusi yang efisien. Hal ini juga berimbas kepada semakin tertinggalnya metode tradisional karena tidak mampu lagimemberikan kemajuan atau perkembangan dalam industri. Dengan memahami industri internet, manusia dapat mengimbangi kompleksitas tersebut dan memanfaatkan internet pada mesin-mesin operasional untuk mendapatkan solusi serta inovasi baru.

Inti dari industri 4.0 adalah perangkat internet berjalan selaras dengan pekerjaan manusia. Sehingga untuk menjalankan industri berbasis internet, diperlukan sumber daya manusia yang memiliki kemampuan dan keahlian untuk memahami perangkat internet itu sendiri. Oleh sebab itu, kemampuan menjalankan internet sangat penting bagi 
seorang pekerja humas, dalam konteks kehumasan. Gilchrist bahkan menyarankan organisasi untuk menyiapkan tenaga ahli analitik data atau teknisi elektro agar dapat memaksimalkan sumber-sumber dari industri 4.0 seperti penggunaan big data dan meta data. Membicarakan industri 4.0 juga berarti membicarakan inovasi yang dapat dilakukan untuk mengembangkan industri. Dalam konteks kehumasan pada khususnya, perlu terus beradaptasi dan mengenali strategi-strategi baru yang sedang tumbuh dan berkembang. Karena umumnya, seperti yang disampaikan sebelumnya, strategi berbasis industri internet memberikan solusi yang tidak bisa diatasi melalui metode tradisional.

Sebelum membahas mengenai industri yang tumbuh dalam lingkup kehumasan, sebaiknya kita memahami terlebih dahulu apa yang dimaksud dengan kehumasan. Botan dan Hazleton (Watson \& Noble, 2007) mendefinisikan kehumasan sebagai proses yang mengusahakan adanya kontrol simbolis atas disposisi evaluatif dan perilaku publik atau klien yang relevan. Sementara Bernays menjelaskan definisi kehumasan dengan menekankan peran persuasifnya bahwa yang dimaksud dengan kehumasan adalah usaha untuk merekayasa dukungan publik (Watson \& Noble, 2007). Selain definisi dari para ahli, Institute of Public Relations di Inggris juga memberikan definisi kehumasan secara praktis. Menurut institusi ini, kehumasan adalah praktik yang disengaja, direncanakan dan berkelanjutan untuk memelihara hubungan suatu organisasi dan publiknya (Warnaby \& Moss, 1997). Dari beberapa definisi di atas dapat kita simpulkan bahwa kehumasan adalah proses usaha untuk membangun dan memelihara hubungan dengan publik yang bertujuan untuk merekayasa dukungan publik untuk organisasi atau perusahaaan.

Fawkes merangkum fungsi humas yang diuraikan L'Etang (Fawkes, 2012). Ia menyebutkan ada tiga fungsi dari humas yaitu representational, dilogic dan advisory. Fungsi representational meliputi penggunaan bahasa, seperti kegiatan retorika, orasi dan avokasi, dan gambaran yang bertujuan untuk merepresentasikan organisasi. Fungsi kedua adalah dialogic, yaitu fungsi yang meliputi kegiatan negosiasi dan usaha-usaha untuk mencapai kesepahaman. Seorang praktisi humas dituntut untuk menjadi jembatan antara publik internal dan publik eksternal organisasi. Oleh sebab itu sangat penting bagi seorang humas untuk cermat dalam menyimak pandangan lain dari khalayaknya. Fungsi ketiga adalah advisory, yaitu fungsi yang meliputi kegiatan konseling. Peran ini bertanggungjawab untuk menjalankan rencana kampanye dari organisasi serta bertugas untuk mengatasi dan memanajemen krisis yang dihadapi. Penting untuk memunculkan fungsi humas dalam pembahasan mengenai strategi humas dalam industri 4.0, karena penggunaan strategi yang akan dijelaskan nantinya juga sering digunakan dalam bidang komunikasi lainnya seperti komunikasi pemasaran dan periklanan. Namun secara umum pembeda antara strategi humas dengan strategi pemasaran adalah fungsi dan tujuannya. Sebagai contoh, penggunaan internet buzzer dalam ranah pemasaran periklanan adalah menggunakan kelimpahan informasi untuk mencapai tindakan pembelian dari calon konsumen. Sementara dalah ranah humas, 
tujuannya adalah untuk memenuhi fungsi humas itu sendiri yaitu membangun reputasi, memperbaiki citra, mengatasi krisis organisasi dan lain sebagainya.

Keterbukaan akses internet yang begitu besar dan masifnya penggunaan sosial media memungkinkan setiap orang untuk mengutarakan pendapatnya. Khalayak juga semakin mudah tersambung dengan berbagai organisasi. Kondisi ini dapat dimanfaatkan praktisi humas untuk mengelola hubungan dengan publiknya secara digital. Beberapa tahun belakangan muncul istilah humas digital, sekaligus mempertemukan humas dengan industri 4.0 yang memanfaatkan ruang internet. Dalam penelitian terkait humas digital terdapat tiga terminologi yang sering digunakan, yaitu "website atau humas berbasis web", "humas online" dan "humas yang menggunakaninternet" (Huang, Wu, \& Huang, 2017). Meskipun telah banyak penelitian tekait dengan terminologi tersebut, ternyata masih cukup sedikit definisi kongkrit terkait humas digital. Huang, Wu dan Huang mendefinisikan humas digital sebagai "manajemen komunikasi antara organisasi dan publiknya melalui aplikasi internet" (Huang et al., 2017). Sementara Gifford menjelaskan bahwa humas digital merupakan serangkaian kegiatan yang meliputi mengeluarkan rilis online untuk memberikan informasi kepada stakeholder tentang layanan mereka. Ia juga memfokuskan humas digital dalam fungsinya untuk meningkatkan kekuatan jaringan jurnalisme dan menyebarkan informasi melalui internet (Gifford, 2010). Dalam menjalankan tugasnya, menurut Gifford praktisi humas digital memiliki dua tujuan yaitu "membangun pemahaman dan kredibilitas institusi melalui press release kepada khalayak yang lebih besar serta memfokuskan aspek khusus dari institusi kepada khalayak yang cocok" (Gifford, 2010).

Humas digital telah berkembang sangat pesat hanya dalam beberapa tahun. Banyak strategi baru bermunculan untuk membantu humas digital mencapai tujuannya. Dengan hadirnya internet, humas digital mendapatkan ruang strategis untuk terus menyajikan informasi kepada khalayak, misalnya dengan mengoptimalisasi sistem pencarian online dan beberapa strategi yang akan diuraikan pada tulisan ini. Praktisi humas digital juga perlu aktif dalam jejaring sosial untuk membangun hubungan dan mengelola reputasi organisasi (Fawkes, 2012).

\section{Word-of-Mouth dan Internet Buzzer}

Anderson mendefinisikan word-of-mouth sebagai komunikasi informal antara pihak yang dekat tentang bagaimana penilaian mereka mengenai barang dan jasa tertentu (Ring, Tkaczynski, \& Dolnicar, 2014). Sementara Bristor menjelaskan bahwa word-of-mouth adalah suatu bentuk komunikasi interpersonal yang melibatkan informasi nonkomersil tentang suatu produk, jasa atau sebuah merk (Larceneux, 2013). Konsumen yang belum pernah memiliki pengalaman menggunakan suatu barang atau jasa biasanya cenderung untuk mencari informasi terkait suatu produk melalui pengalaman pribadi orang lain. Dari penelitian peneliti sebelumnya, Larceneux menyimpulkan bahwa word-of-mouth telah menjadi cara efektif untuk mempengaruhi calon konsumen karena semakin banyak produk atau jasa menerima rekomendasi yang baik, semakin 
ingin calon konsumen ingin membelinya (Larceneux, 2013). Para peneliti memberikan pandangan yang lebih luas mengenai efek dari word-of-mouth, lebih dari mempengaruhi keputusan membeli. Luarn et al menyimpulkan dari penelitian terdahulu bahwa word-of-mouth tidak hanya mempengaruhi pilihan konsumen dan minat beli, namun juga membentuk sikap sebelum membeli dan perilaku selanjutnya terhadap brand yang mereka gunakan (Luarn, Huang, Chiu, \& Chen, 2016).

Dengan kehadiran internet, proses word-of-mouth ini merambah melalui sistem pencarian seperti google dan yahoo. Lewat situs pencarian ini calon konsumen mencari berbagai ulasan tentang suatu barang atau jasa yang kemudian mereka temukan dalam bentuk blog, berita, forum atau video ulasan. Untuk membedakan dengan word-of-mouth yang dilakukan secara tradisional, proses melalui perangkat teknologi ini disebut juga e-WOM atau electronic word-of-mouth. Definisi electronic word-of-mouth adalah segala pesan dari komunikasi informal yang ditujukan untuk konsumen melalui teknologi berbasis internet yang berhubungan dengan karakteristik barang, jasa atau penjualnya (Ring et al., 2014). Perkembangan media sosial banyak membantu tumbuhnya e-WOM sebagai salah satu strategi untuk mempengaruhi opini publik mengenai suatu produk. Banyak perusahaan yang melihat potensi media sosial ini kemudian memanfaatkannya untuk mempraktekkan e-WOM seperti mengadakan lomba menulis ulasan, foto atau video pengalaman pengguna terhadap suatu produk. Dengan usaha ini rekomendasi mengenai produk mereka akan membanjiri media sosial. Apabila rekomendasi ini positif maka akan berdampak baik kepada reputasi perusahaan yang berusaha mereka bangun.

Ring et al (2014) merangkum beberapa aktivitas e-WOM yang membuatnya lebih menguntungkan dibanding menggunakan word-of-mouth secara tradisional. Pertama, arah komunikasi dalam e-WOM tidak lagi bersifat one-to-one seperti halnya WOM tradisional. E-WOM mampu memperluas arah komunikasinya menjadi one-to-many atau many-to-many. Kedua, karena mampu mengjangkau arah komunikasi yang luas, e-WOM dapat diakses secara global. Ketiga, e-WOM memungkinkan terjadinya proses pertukaran informasi dengan orang asing yang memiliki pengalaman untuk merekomendasikan produk. Hal ini tidak dapat dilakukan WOM secara tradisional yang lingkup sempit berupa teman dan keluarga. Keempat, e-WOM memungkinkan pesan untuk dialirkan melalui berbagai macam media. Tidak hanya dalam bentuk lisan dalam kondisi bertatap muka seperti WOM tradisional, e-WOM dapat berbentuk tulisan, gambar, atau video yang bisa diunggah ke media sosial atau disebarkan melalui mailing list. Kelima, dengan menggunakan media online materi e-WOM dapat disimpan dan digunakan kembali saat dibutuhkan. Namun beberapa peneliti masih memperdebatkan e-WOM dengan kekurangannya, salah satunya adalah ketidakakuratan informasi yang disebarkan secara massif lewat internet. Tham, Vroy dan Mair (Ring et al., 2014) berargumen bahwa WOM online mungkin akan diragukan keakuratan dan tidak dipercaya karena pesannya diolah oleh orang asing atau bahkan anonim yang tidak diketauhi kredibilitasnya. 
Penggunaan e-WOM yang semakin umum kemudian memunculkan berbagai konsep yang berhubungan dengan penyebaran pesan melalui internet, salah satunya adalah internet buzz. Ada artikel ilmiah mendefinisikan buzz sebagai sinonim dari word-of-mouth, namun belakangan berkembang pemahaman bahwa buzz digunakan untuk menunjukkan volume atau intensitas word-of-mouth terhadap suatu produk dan berfokus pada kiriman online (Houston, Kupfer, Hennig-Thurau, \& Spann, 2018). Konsep e-WOM ini sering kita temui juga dalam video review dan unboxing yang ramai di YouTube, atau artikel rekomendasi yang ditulis para blogger, baik di blog mereka sendiri atau dalam sebuah forum. Review dan komentar dari para pembuat konten ini tanpa sadar membentuk pandangan kita terhadap suatu produk

Seperti yang diungkapkan Houston et al (2018), membicarakan buzzer berarti menbicarakan volume, artinya buzz memiliki dimensi kuantitatif. Volume diartikan sebagai jumlah orang yang membicarakan suatu produk. Selain dimensi ini, buzz juga memiliki dimensi kualitatif yaitu valence atau valensi. Valensi diartikan sebagai lebih menguntungkan atau kurang menguntungkan penilaian yang dibuat mengenai suatu produk (Larceneux, 2013). Artinya pendapat yang dianggap kurang menguntungkan akan menyebabkan suatu produk menjadi dianggap tidak baik, sementara produk yang mendapatkan ulasan yang menguntungkan akan menaikkan ekspektasi yang baik dari khalayak kepada produk tersebut (Larceneux, 2013). Karena dapat dipandang melalui dua dimensi ini, maka dapat disimpulkan bahwa tidak selalu suatu merk atau produk yang mendapat banyak publikasi dari buzzer menjadi produk yang baik, namun juga juga perlu dilihat apakah rekomendasi yang diberikan positif atau negatif. Secara umum, dilihat dari kedua dimensi ini kita mengetahui bahwa buzz memiliki kekuatan yang cukup besar untuk melakukan persuasi terhadap khalayak, baik secara aktif maupun secara pasif.

Liang et al melakukan sebuah riset yang menggambarkan bagaimana praktek buzz mampu membangun reputasi, namun penelitian ini dispesifikkan dalam lingkup artikel ilmiah yang dipublikasikan di internet. Hasil temuan dari penelitian ini menunjukkan bahwa ilmuwan juga membangun buzz melalui media sosial sama seperti mereka menarik publik lewat media massa. Hal ini ditujukan selain untuk memperkaya pertukaran informasi antara ilmuwan dan publik, juga untuk melakukan komunikasi publik agar mereka mendapatkan lebih banyak perhatian (Corley et al., 2014) Buzznet has acquired music-focused blogs and brought on Universal Music Group as a content partner and equity holder with the goal of creating an online music destination to rival MySpace and Facebook. Buzznet began as a site for uploading camera-phone pictures, but soon became a very music-focused site and for the last three years has served as the official online community for the Coachella music festival. It has created similar services for the Vans Warped tour. The site provides individual artist searches and profiles and social networking components. It has aggressively recruited artists and added full-song streaming and music videos.","author":[ [ “"dropping-pa rticle":",",family":"Corley","given":"Eliza beth A.","non-dropping-particle":,",,"parse- 
names":false,"suffix":"" $\},\{$ "dropping-pa rticle":",,"family":"Yeo","given":"Sara K.","non-dropping-particle":",","parse-na mes":false,"suffix":", $\},\{$ "dropping-part icle":",,"family":"Xenos","given":"Mic hael","non-dropping-particle":",","parsenames":false,"suffix":"”\}, \{“dropping-particle ":,",,'family":"Su","given":,Leona Yi-Fan"," non-dropping-particle":",","parse-names":fal se,"suffix":","\},\{“dropping-particle":,",,"fami ly":"Nealey","given":"Paul","non-droppingparticle":",,"parse-names":false,"suffix":"”,,\{ “dropping-particle":",,,'family":"Liang","give n":"Xuan","non-dropping-particle".,",,"parsenames":false,"suffix":"', $\},\{$ “dropping-particl e":",,"family":"Scheufele","given":"Dietram A.,",non-dropping-particle":",","parse-name s":false,"suffix":", \}, \{“dropping-particle":"”, "family":"Brossard","given":"Dominique"," non-dropping-particle":",","parse-names":fal se,"suffix":","\} ],"container-title":"Journalism \& Mass Communication Quarterly","id":" ITEM-1","issue":"4","issued": \{“date-parts": [[“2014”]]\}," page":"772-791"," title":" Building Buzz","type":"article-journal","volu me":"91"\},"uris":[“http://www.mendeley.com/ documents/?uuid=3160de3b-2260-4132-824099c61 eb2a53e"] \}],"mendeley": \{“formattedCi tation":"(Corley et al., 2014. Hasil dari usaha mereka aktif di media sosial adalah khalayak mereka lebih banyak dan jika ada penelitian yang mereka publikasikan melalui media sosial, artikel tersebut akan mendapatkan lebih banyak perhatian dibanding hanya mempublikasikan di jurnal. Dalam dunia akademik, penelitian akan dikatakan penting dan bergengsi apabila mendapatkan banyak perhatian dan banyak dikutip, sehingga membangun buzz di media sosial dapat dikatakan menguntungkan bagi reputasi para ilmuwan.

Dengan menggunakan buzzer dan e-WOM, humas tidak hanya dapat membangun reputasi, namun juga dapat menutupi krisis yang sedang dihadapi. Beberapa perusahaan di Indonesia telah mencoba strategi ini di akun media sosial mereka. Misalnya mereka hanya memberikan reaksi repost atau retweet hanya kepada kiriman positif pada waktu akun itu tengah diserang komentar negatif.

Membicarakan buzzer juga akan membawa kita pada fenomena yang ramai dibicarakan di Indonesia yaitu tentang cyber army atau pasukan siber. Di Indonesia, pasukan siber ini lebih banyak dikenal untuk keperluan politik, namun dengan karakteristik buzzer-nya, juga bisa digunakan sebagai strategi kehumasan. Jika ingin membentuk pasukan ini untuk menjadi buzzer yang bertugas menutupi krisis, humas dapat mengatur strategi tertentu. Tugas yang bisa diinstruksikan seperti menulis tanggapan yang positif, melakukan reaksi terhadap kiriman atau membantu suatu hashtag yang mendukung organisasi agar menjadi viral.

\section{Tumbuhnya Aktivitas Social Media Activist}

Kemampuan media sosial untuk menyebarkan pesan kepada khalayak yang besar juga dimanfaatkan oleh sejumlah aktivis media sosial, untuk menjalankan perannya Aktivisme media sosial atau juga yang sering disebut aktivisme online, didefinisikan sebagai "penggunaan teknologi jejaring sosial untuk mengoranisir dan mengkoordinasi tindakan di dunia nyata, juga membentuk bagaimana orang tertarik pada protes politik dan bagaimana 
peneliti memahami pergerakan sosial" (Brown, Ray, Summers, \& Fraistat, 2017). Dari definisi ini dapat disimpulkan bahwa gerakan aktivis media sosial tidak hanya menargetkan massa yang besar, namun sampai pada tindakan nyata. Bahkan mampu untuk mengarahkan ketertarikan seseorang kepada isu tertentu melalui situs jejaring sosial. Taylor dan Sen Das menjelaskan tujuan spesifik dari aktivis media sosial adalah untuk menciptakan jaringan advokasi dalam suatu gerakan sosial (Veil, Reno, Freihaut, \& Oldham, 2014).

Pada awal kemunculannya, aktivisme media sosial merupakan mekanisme untuk membuat orang lain merasa terhubung dengan berbagai masalah sosial yang membuat mereka berminat. Aktivisme pada media sosial tumbuh dan menjadi populer karena media sosial sangat erat kaitannya dengan pembangunan identitas kolektif, seperti isu sosial apa yang mereka minati dan sebagainya, identitas kolektif inilah yang menjadi tujuan dari aktivis media sosial (Gerbaudo \& Treré, 2015).

Yang mencoba menbagi klasifikasi gerakan aktivis online menjadi empat yaitu aktivisme yang berfokus pada isu kultural, sosial, politik, dan nasionalitas (Yang, 2009). Inti dari kegiatan aktivisme adalah menggugat legitimasi sehingga orang sadar akan suatu isu. Para aktivis media sosial ini juga mengajak orang lain untuk memberikan solusi, baik itu berupa tindakan atau pemikiran.

Aktivis media sosial ini dapat menjadi salah satu strategi untuk mencapai tujuan humas, khususnya untuk memenuhi fungsi dialogis. Ada krisis dimana humas harus melakukan dialog kepada publiknya mengenai suatu permasalahan, pada situasi seperti ini humas dapat melibatkan aktivis media sosial. Terdapat beberapa alasan yang melatarbelakangi, yaitu mengajak aktivis media sosial memungkinkan humas untuk menggiring dukungan mengenai isu yang mereka bawa, kemudian dengan menggunakan fasilitas internet dan media sosial dapat mengurangi biaya yang harus dikeluarkan.

Aktivisme memerlukan massa yang besar dalam melakukan tugasnya. Melalui media sosial mereka dapat mengumpulkan para pendukung tersebut dengan lebih besar dibanding mereka harus mengumpulkannya di dunia nya. Selain itu, para pendukung ini juga bergabung karena mengikuti suatu gerakan tidak perlu turun langsung, dapat dilakukan di rumah, di kantor atau di sekolah selama mereka dapat mengakses media sosial. Semakin besar dan kaya massa yang berhasil dikumpulkan oleh aktivis media sosial, maka mereka akan menggunakan strategi yang mirip dengan target mereka dan gerakan ini tidak lagi bergantung pada publikasi media (Veil et al., 2014). Masa yang telah terkumpul dan terorganisir ini akan diarahkan untuk menyerang legitimasi dan reputasi targetnya. Karena ranahnya adalah media sosial, maka aksi yang dilakukan masih pada interaksi yang biasa dilakukan di media massa seperti retweet, menyukai suatu kiriman yang disebarkan oleh suatu gerakan. Aktivitas ini kemudian mengarah kepada terminologi yang populer dalam pembahasan aktivisme online yaitu "slacktivism" (Veil et al., 2014). Istilah ini merupakan kombinasi dari kata "slacker" yaitu kendur dan "activism" atau aktivisme yang menggambarkan ada keterputusan antara kesadaran dan aksi ketika seseorang sedang menggunakan media sosial (Glenn, 2015). 
Hal ini mengarah pada perasaan senang sudah terlibat dalam suatu aksi aktivisme tapi hanya sebatas melihat, menonton, atau menekan tombol like di sosial media, tanpa ada keinginan untuk terlibat secara langsung.

Melibatkan aktivis media sosial dapat menjadi sebuah langkah yang baik bagi organisasi untuk mempertahankan reputasinya. Dalam konteks Indonesia, sebagai contoh organisasi atau perusahaan yang dalam produksinya menimbulkan isu-isu lingkungan, maka mereka dapat melibatkan aktivis media sosial yang bergerak di bidang lingkungan. Keterlibatan aktivis ini bisa dalam bentuk kampanye di media sosial atau ketika dalam kondisi berdialog dengan publiknya untuk mendapatkan dukungan yang lebih besar. Ketersediaan media sosial yang begitu beragam dapat digunakan untuk menyebarkan pesan dalam bermacam bentuk. Pesan tidak harus melulu berupa teks namun juga dapat berupa audio visual seperti video di YouTube, Facebook atau Instagram, serta berbentuk foto dan infografis.

Pertumbuhan aktivis media sosial ini juga dapat menjadi masukan bagi organisasi untuk tidak menganggap remeh ancaman dan kritik dari aktivis walaupun hanya melalui internet dan media sosial. Karena memiliki kemudahan untuk menghimpun pendukung yang besar, aktivis media sosial ini dapat menjadi ancaman bagi reputasi organisasi. Akan sangat berbahaya bagi organisasi apabila menyerang menggunakan alat-alat penyebar pesan milik mereka seperti hoax atau membajak media sosial (Veil et al., 2014). Mendiamkan atau berusaha tidak peduli pada kritik ini juga tidak akan menjadi jalan keluar yang baik. Karena gerakan aktivis semacam ini tidak akan berhenti sebelum organisasi memberikan reaksi kepada kritik mereka, bahkan mereka hanya akan terpuaskan apabila suatu organisasi sampai merombak kebijakan yang menurut para aktivis ini tidak menguntungkan (Veil et al., 2014).

\section{Penggunaan Search Engine Optimization}

Strategi selanjutnya yang dapat dilakukan humas digital adalah mengoptimalkan search engine optimization (SEO). Konsep mengenai SEO juga dimiliki oleh komunikasi pemasaran dalam tujuan agar calon pembeli sering menemukan konten suatu produk dan jadi memiliki keinginan untuk membeli produk tersebut. Namun pada pembahasan ini difokuskan penggunaan SEO dalam konteks hubungan masyarakat. Penggunaan SEO sendiri lebih kepada internet dalam ranah search engine. Namun dalam prakteknya menggunakan media sosial juga dapat mengoptimalkan peran dari SEO. Definisi dari SEO adalah sebuah proses usaha untuk mendapatkan peringkat tertinggi dalam web page atau domain untuk kata kunci tertentu (Evans, 2007). Semakin tinggi ranking yang didapatkan oleh SEO atau dengan kata lain, dalam pencarian internet domain kita pada urutan teratas, maka domain tersebut dapat dikatakan populer. SEO merupakan cara paling efektif untuk mendapatkan perhatian pengguna yang terkoneksi internet (Yalçin \& Köse, 2010)which index and class other web sites according to their keywords, explanations and contents and make it easier and faster to reach obtained site-search results, are called as search engines. SEO '"Search Engine Optimization'" is the one of the widely used technique that provides web sites fast reachable. In this work we explained required information 
to make a web site more indexed by search engines and considering their keywords make them first listed. (C) 2010 Published by Elsevier Ltd.","author":[\{“dropping-pa rticle":",",family":"Yalçin","given":"Nurs el","non-dropping-particle":",","parse-nam es":false,"suffix":"”'\},\{“dropping-particle" :"',"’family":"Köse","given":"Utku","nondropping-particle":",","parse-names":false ,"suffix":"',\}],"container-title":"Procedia Social and Behavioral Sciences","'id":"'ITEM1","issue":"July 2009","issued": ‘“dateparts":[["20 010 "] ] \},"page":" 487 493","title":"What is search engine optimization: SEO?","type":"article-journal", "volume":"9"],"uris":[“http://www.mendeley. com/documents/?uuid=456b5bad-6759-4e2986c2-7de45df074c2"]\}],"mendeley": \{“formatt edCitation":"(Yalçin \& Köse, 2010.

Penerapan SEO dalam ranah humas digital dapat sangat membantu dalam hal visibilitas website organisasi. Tujuan utama dari SEO adalah membuat website atau domain mudah ditemukan, serta selalu muncul pada halaman pertama index berbagai mesin pencarian. Ketika website organisasi selalu pada posisi strategis seperti ini akan memperbesar peluang bagi khalayak untuk mengakses website tersebut. Kemudian karena sering dikunjungi dan mencapai popularitas yang dirasa cukup, maka kegiatan humas digital akan sangat terbantu. Konten-konten yang berisi layanan, informasi, laporan, berita rilis terkait organisasi akan lebih banyak mendapat perhatian dibandingkan membiarkan website tumbuh apa adanya (Evans, 2007). Karena konteksnya adalah humas digital, maka SEO pada pembahasan ini akan lebih banyak berbicara mengenai pemanfaatannya dalam membangun reputasi organisasi.

Sebagai awal, organisasi harus memahami apa tujuan sebenarnya mengembangkan SEO yaitu menyediakan informasi yang berisi materi organisasi atau konten terkait lainnya. Seberapa penting untuk mengaplikasikan SEO ini sebenarnya tergantung pada keputusan organisasi, apabila mereka memiliki konten yang sangat bernilai dan orang perlu untuk mengetahuinya, sebagai contoh kampanye lingkungan dan sebagainya, maka organisasi memerlukan SEO. Cara kerja SEO adalah menggunakan algoritma untuk membuat domain tertentu berada dalam indeks teratas, misalnya pada halaman pertama atau 10 konten pertama. Westfall menjelaskan bahwa algoritma tidak memiliki kemampuan untuk membaca seberapa sering suatu website dikunjungi atau dilihat oleh pengguna (Evans, 2007). Evans juga menjabarkan taktik apa yang harus dilakukan oleh humas digital untuk melakukan search engine optimization, yaitu membuat konten yang berkualitas, memasukkan kata kunci yang relevan, kepemilikan metabahasa yang kuat, tautan internal menuju website, serta tautan eksternal (backlinks) menuju website.

Sebagian besar taktik di atas digunakan untuk mengoptimalisasikan mesin pencarian dalam konteks website, namun karena pembahasan harus mengerucut pada peran media sosialnya, maka yang akan dibahas lebih jauh hanya tautan eksternal. Tautan eksternal merupakan taktik yang sangat cocok digunakan dalam konten organisasi di media sosial. Apabila berhasil memanfaatkan backlinks maka pertumbuhan pengunjung pada website dapat dioptimalkan, semakin banyak pengunjung 
website maka ranking website tersebut di mesin pencarian juga semakin tinggi. Sumber lainnya yang juga bisa menjadi pertimbangan untuk memanfaatkan tautan ekstenal ini yaitu berita dan informasi yang benar, melalui blogger, serta WIFM (What's in it for me?) atau partner yang menghubungkan diri dengan alasan tertentu (Evans, 2007). Untuk mendapatkan hasil yang optimal, penerapan tautan eksternal ini bisa dibarengi dengan strategi lainnya seperti buzzer. Pada beberapa website tertentu menerapkan kolom khusus yang berisi konten yang disiapkan oleh publik yang kemudian membangun traffic dalam website lalu juga menaikkan rankingnya di mesin pencarian.

Media sosial tidak bisa dipandang remeh dalam humas digital, khususnya ketika mendiskusikan SEO. Menurut Fishkin, laman resmi organisasi seperti Facebook page dan profil Twitter merupakan bagian dari algoritma Google dan Bing untuk hasil pencarian di mesin mereka (Geho \& Dangelo, 2012). Strategi yang dapat digunakan oleh humas digital adalah membuat konten yang berkualitas di akun media sosial organisasi dengan menambahkan tautan menuju laman website. Cara yang juga sering ditemukan adalah membuat konten di website dan mengirimkan tautannya di media sosial, sehingga bagi pengguna yang ingin membaca kontennya secara lengkap harus menuju tautan tersebut. Memiliki buzzer akan sangat menguntungkan dalam strategi ini karena membantu menyebarkan link dari kiriman yang dibuat. Selalu menyematkan tautan pada laman profil di media sosial organisasi juga penting, selain untuk menambah pengunjung website juga memudahkan khalayak untuk mencari informasi terkait organisasi.
Mengoptimalkan kata kunci tertentu untuk menaikkan popularitas website juga dapat dilihat sebagai usaha untuk membangun reputasi. Misalnya humas digital bisa merancang suatu kampanye yang memiliki kata kunci generik. Kekhususan dari nama kampanye misalnya, dapat di-boost melalui media sosial dengan tautan ke website. Dengan kemampuan SEO, kampanye tersebut bisa saja menempati index teratas di mesin pencarian. Sehingga lebih banyak pengguna yang mengakses kampanye dan reputasi yang ingin dibangun melalui kampanye tersebut dapat tercapai.

\section{KESIMPULAN}

Revolusi industri saat ini telah memasuki era keempat atau industri 4.0. Pada tahapan industri ini internet memiliki peran yang besar untuk berkolaborasi dengan kinerja manusia. Perangkat terhubung dengan mesin dan semua berjalan serba otomatis, tenaga manusia dan dana operasional dapat ditekan. Namun sebagai konsekuensinya manusia dituntut untuk terus berinovasi untuk memecahkan masalah. Kompleksitas masalah pada industri 4.0 juga lebih tinggi sehingga solusi yang bersifat tradisional tidak lagi mampu mengatasinya. Setiap orang dari berbagai bidang industri harus mencari solusi baru menggunakan perangkat digital yang mampu menjawab problematika yang ada.

Kehumasan merupakan rangkaian kegiatan untuk membangun, mengelola, hingga memanipulasi dukungan publik. Memasuki era digitalisasi industri kehumasan mulai berkembang ke ranah digital dan mendapatkan nama baru, humas digital. Kehadiran internet 
mampu memberikan keuntungan bagi humas digital untuk menjalankan tugasnya. Humas digital memanfaatkan internet dengan kemampuannya untuk menjangkau khalayak yang lebih luas dan besar, sehingga khalayak itu tidak lagi terbatas pada ruang geografis saja bahkan terus meluas hingga ranah global. Agar mampu memaksimalkan fitur yang dimiliki internet, seorang humas digital perlu memiliki keterampilan dan selalu terbuka terhadap inovasi yang bermunculan

Dalam mempengaruhi dukungan publik yang ada di dunia maya dan mempertahankan reputasi organisasi, banyak strategi baru bermunculan. Strategi yang ditawarkan memanfaatkan internet, khususnya media sosial. Bagi humas digital, media sosial merupakan pintu masuk menuju khalayak yang lebih besar. Lewat media sosial pengguna saling berbagi informasi dan berkomunikasi, bahkan kepada orang yang tidak mereka kenal. Jika mampu mendapatkan perhatian di media sosial, maka untuk mencapai tujuan humas digital akan sangat dimudahkan. Untuk mencapai goal tersebut maka ada beberapa strategi yang ditawarkan meliputi electronic word-ofmouth, internet buzzer, aktivis media sosial dan search engine optimization. Sebagai salah satu kajian komunikasi, humas digital diharapkan mampu memberikan signifikansi praktis dalam penggunaan strategi dan terus bertransformasi menggunakan inovasi baru sehingga semakin banyak pula masukan untuk keilmuan komunikasi

\section{DAFTAR PUSTAKA}

Baldassari, P., \& Roux, J. D. (2017). Industry 4.0 Preparing for the future. People \& Strategy, 20-23. https://doi.org/10.1097/00006223198105000-00004

Brown, M., Ray, R., Summers, E., \& Fraistat, N. (2017). \#SayHerName: a case study of intersectional social media activism. Ethnic and Racial Studies, 40(11), 18311846. https://doi.org/10.1080/01419870.2 017.1334934

Corley, E. A., Yeo, S. K., Xenos, M., Su, L. Y.-F., Nealey, P., Liang, X., ... Brossard, D. (2014). Building Buzz. Journalism \& Mass Communication Quarterly, 91(4), 772-791. https://doi. org/10.1177/1077699014550092

Evans, M. P. (2007). Analysing Google rankings through search engine optimization data. Internet Research, 17(1), 21-37. https:// doi.org/10.1108/10662240710730470

Fawkes, J. (2012). What is Public Relations. In A. Theaker (Ed.), The Public Relations Handbook (4th editio, hal. 3-20). London and New York: Rouledge.

Fuchs, C. (2018). Industry 4.0: The digital German ideology. TripleC, 16(1), 280-289.

Geho, P. R., \& Dangelo, J. (2012). The Evolution of Social Media in as A Marketing Tool For Entrepreneurs. Entrepreneurial Executive, $17,61-68$.

Gerbaudo, P., \& Treré, E. (2015). In search of the 'we' of social media activism: introduction to the special issue on social media and protest identities. Information Communication and Society, 18(8), 865-871. https://doi.org/10.1080/136911 8X.2015.1043319

Gifford, J. (2010). Digital Public Relations: E-Marketing's Big Secret. Continuing Higher Education Review, 74, 62-72. 
Gilchrist, A. (2016). INDUSTRY 4.0 THE INDUSTRIAL INTERNET OF THINGS. California: Apress.

Glenn, C. L. (2015). Activism or "Slacktivism?": Digital Media and Organizing for Social Change. Communication Teacher, 29(2), 81-85. https://doi.org/10.1080/17404622 .2014 .1003310

Houston, M. B., Kupfer, A. K., Hennig-Thurau, T., \& Spann, M. (2018). Pre-release consumer buzz. Journal of the Academy of Marketing Science, 46(2), 338-360. https://doi.org/10.1007/s11747-0170572-3

Huang, Y. H. C., Wu, F., \& Huang, Q. (2017). Does research on digital public relations indicate a paradigm shift? An analysis and critique of recent trends. Telematics and Informatics, 34(7), 1364-1376. https:// doi.org/10.1016/j.tele.2016.08.012

Jankowska, B., \& Götz, M. (2017). Clusters and Industry 4.0 - do they fit together? European Planning Studies, 25(9), 16331653.

Kietzmann, J. H., Hermkens, K., McCarthy, I. P., \& Silvestre, B. S. (2011). Social media? Get serious! Understanding the functional building blocks of social media. Business Horizons, 54(3), 241-251. https://doi. org/10.1016/j.bushor.2011.01.005

Larceneux, F. (2013). Buzz and Recommendations on the Internet. What Impacts on Box-Office Success? Recherche et Applications en Marketing (English Edition), 22(3), 43-62. https://doi. org/10.1177/205157070702200304

Luarn, P., Huang, P., Chiu, Y. P., \& Chen, I. J. (2016). Motivations to engage in wordof-mouth behavior on social network sites. Information Development, 32(4), 1253-1265. https://doi. org/10.1177/0266666915596804

Popkova, E. G., Ragulina, Y. V., \& Bogoviz, A. V.
(2019). Industry 4.0: Industrial Revolution of the 21st Century. Cham: Springer.

Ridley, D. (2012). The Literature Review A Stepby-Step Guide for Students (2nd Edition). London: Sage Pub.

Ring, A., Tkaczynski, A., \& Dolnicar, S. (2014). Word-of-Mouth Segments. Journal of Travel Research, 55(4), 481-492. https:// doi.org/10.1177/0047287514563165

Ustundag, A., \& Cevikcan, E. (2018). Industry 4.0: Managing The Digital Transformation. Cham: Springer.

Veil, S. R., Reno, J., Freihaut, R., \& Oldham, J. (2014). Online activists vs. Kraft foods: A case of social media hijacking. Public Relations Review, 41(1), 103-108. https:// doi.org/10.1016/j.pubrev.2014.11.017

Warnaby, G., \& Moss, D. (1997). The Role of Public Relations in Organisations. In P. J. Kitchen (Ed.), Public Relations: Priciples and Practice. London: Thomson.

Watson, T., \& Noble, P. (2007). Evaluating Public Relations A Best Practice Guide to Public Relations Planning, Research and Evaluation (2nd editio). London and Philadelphia: Kogan Page.

Yalçin, N., \& Köse, U. (2010). What is search engine optimization: SEO? Procedia Social and Behavioral Sciences, 9(July 2009), 487-493. https://doi.org/10.1016/j. sbspro.2010.12.185

Yang, G. (2009). Online activism. Journal of Democracy, 20(3), 33-36. 
164 | Komunikasi, Vol. XIII No. 02, September 2019: 149-164 